\title{
【特＼cjkstart集】女性外科医師の進出をめぐって（第30回学術集会ワークショップ3）
}

\section{2 ．女性外科医師の進出と今後}

\author{
独立行政法人国立病院機構横浜医療センター \\ 土井卓子 田辺 美樹子
}

\section{Present and Future of Female Surgeons}

Takako DOI and Mikiko TANABE

Department of surgery, National Hospital Organization Yokohama Medical Center

日本では歴史的にも女性が医学分野に進出することは容易ではなかったが, 女性医師の熱意によって道が開か れ, 女性医師の数は現在増加している。受診者から乳房, 肛門の診察に女性医師を希望する声は多いにもかかわ らず, いまだに外科には女性医師が少ない。女性医師が活躍しにくい理由は妊娠, 出産, 育児との両立が困難で あること, 特に外科系は手技を習得する重要な時期が出産, 育児と重なるため困難が大きい。他方女性受診者の 側は従来の科別医療に満足せず, 女性の特質を理解して全人的に看てくれる女性外来を求めている。とりわけ女 性医師に対しては話を聞いて苦痛に共感し，専門分野だけでなくオールラウンドに対応できる能力を求めてい る。子育てや介護支援を充実して女性医師が活躍できる環境を整備し, 女性医師はニーズに答えた質の良い医療 を提供してゆきたい。

索引用語：女性外科医師（female surgeons），女性外来（women's health clinic）

\section{はじめに}

日本では男女共同参画社会が目指され，男女雇 用機会均等法案の制定により女性の職場進出が進 んでいる。しかしまだ，日本社会は男性中心であ $\eta ，$ 職場での出世は男性優位の場合が多い。さら に女性は常勤になりにくくパートや派遣が多いの が現状である。そのような社会にあっても男女が 同等に勤務できるのが医師の世界である。しかし それでも女性医師が十分に能力を生かして活躍で きているとはいえない。女性医師たちはなぜ自分 たちが望むように，また期待されるように活躍す ることができないのだろうか。その原因と解決策 を検討した。
目的

女性医師の歴史と現状を分析し，女性医師およ び女性医師を取り巻く環境が抱える問題点および その解決のための方策を検討した。同時に受診者 が女性医師に求めているものについて検討した。 医師が女性であることに特別な意義があるのか, 男性ではできない医療上の特殊性があるのかを検 討し，女性医師が現代社会で最も有意義に活躍す るためにどうすればよいのかを考えてみた。

\section{方 法}

1.日本の医学史を検索し，女性医師はいつか ら活躍し，どのような苦労があり，歴史的にどの ような存在意義があったかを検討した。

2 . 現在の女性医師の人数と勤務状況を調査し, 
女性医師の抱える問題点を検討した。

3. 人数の少ない女性外科医師の実態調査を行 い，問題点を検討した。

4. 女性外来が全国に波及した理由と受診者が 女性医師に求めるものを調査し，医師が女性であ ることに特殊な意義があるかどうかを検討した。

5 .女性外来を担当した医師の意見調査を行い, 女性医療には何が必要かを検討した。

\section{結果}

\section{1 、日本女性医師の歴史}

荻野吟子医師が 1885 年公許女医第一号で免許 を取得している。日本の医学教育は, 1868 年医師 免許規則が制定され, 医師免許を取得するには開 業試験に合格するか官立府県立医学校または外国 医学校を卒業することが必要であった。官立府県 立医学校は男制であったため女性が免許を取得す るには開業試験養成機関を卒業して試験に合格し なければならなかった。開業試験養成機関には済 世学舎と成医学校の 2 校があったが成医学校は男 制であり，女性は済世学舎で学ばなければならな かった。しかし 1900 年に済生学舎も風紀を乱すと いう理由で女子禁制となってしまった。1900 年東 京女医学校（現在の東京女子医大）が開設され, 1903 年には済世学舎も共学の同空医学講習会に なり女性医師育成の道が開かれた。第二次大戦中 は各地で女子医学専門学校が開設され，女性医師 育成は一気に進んだ。戦後新制大学へと変化し, 現在に至っている1。荻野吟子医師は自分が若い ころ男性医師による診察で大変苦しい思いをした ことが契機となって同様につらい思いをしている 女性達を助けたいと希望して医師になり活躍し た。当時から女性の進出は男性医師たちから快く 思われておらず，風紀を乱すとさ之言われ，医師 免許を取得することは容易ではなかったようであ る。しかし常に女性の熱意で道が開かれてきた。 また第二次世界大戦中は男性が出征して国内でも 戦場でも医師不足となり，女性医師の活躍は社会 の大きな支えとなった。

\section{2. 女性医師の人数}

1885 年に荻野吟子医師が免許を取得して以来, 女性医師の数は 1965 年 10,128 人 (9.3\%), 2000
年 36,852 人 ( $14.4 \%)$ と着実に増加してきた。医 師国家試験合格者も，1991 年には女性が $19.2 \%$ で あったものが 2002 年には $30.8 \%$ と時代が下がる につれ女性の占める割合が増加している。医師国 家試験の合格率で男女を比較すると 2002 年の データでは男性 $88.9 \%$, 女性 $93.8 \%$ で, 数年間女 性は男性を平均約 $6 \%$ 上回っている。不祥事によ る医師処分例は $1998 \sim 2001$ 年の 3 年間で 143 人 であったが男性 $97.2 \%$ ，女性 $2.8 \%$ であった。こ の結果から女性医師は, 年々増加傾向にあり, 医 師としてのスタート時には男性より成績がよく, 長い目でみても不祥事が少ないと言える。しかし 各科での医師の労働力としての評価は別の問題で ある2)。

\section{診療科別医師数の男女比率}

女性医師がどの科に勤務しているかを調べる と, 平成 12 年には $28.4 \%$ の女性医師が内科に勤 務しておりもっとも多く，眼科に $12.3 \%$ ，小児科 に $11.9 \%$ ，精神科と産婦人科に各 $5.4 \%$ ，麻酔科 $4.4 \%$, 外科 $2.3 \%$, 放射線科 $2.2 \%$ であった。 最近は内科, 精神科, 眼科は減少傾向にあり, 外科, 産婦人科, 麻酔科が増加傾向にあるとい $j^{2)}$ 。学会所属者のうち女性の占める割合が高い のは皮膚科, 眼科, 小児神経科, 小児科であると $\left(j^{3)}\right.$ 。

\section{女性医師の地位および学会活動}

橋本らの調查によれば女性教授は基礎系 32 名 (5.1\%, 東京女子医大を除くと $2.1 \%)$, 臨床系 52 名 $(2.8 \%$, 同 $0.8 \%)$, 女性助教授基礎系 64 名 (13. $1 \%$, 同 $5.9 \%)$, 臨床系 73 名 $(4.5 \%$, 同 $1.8 \%)$ とわずかで, 教授, 助教授, 講師合計しても 597 名 (4.1\%)である。臨床系では基礎系より割合が低 く, 国公立は私立より低い傾向にあるという。学 会理事や評議員に女性が占める割合は調査回答の あった 24 学会中 $0 \%$ 学会が 20 学会で, 会員が $30 \%$ 以上女性である皮膚科学会でも $4.5 \%$, 眼科 学会は $5.5 \%$ ，小児科学会は $2.7 \%$ にずなかった とのことである1”。つまり大学の医局で勤務して いても教職についている女性はごく少数で, 学会 の中でもリーダーシップをとって活躍している女 性医師は少数に過ぎないと言うことができる。 


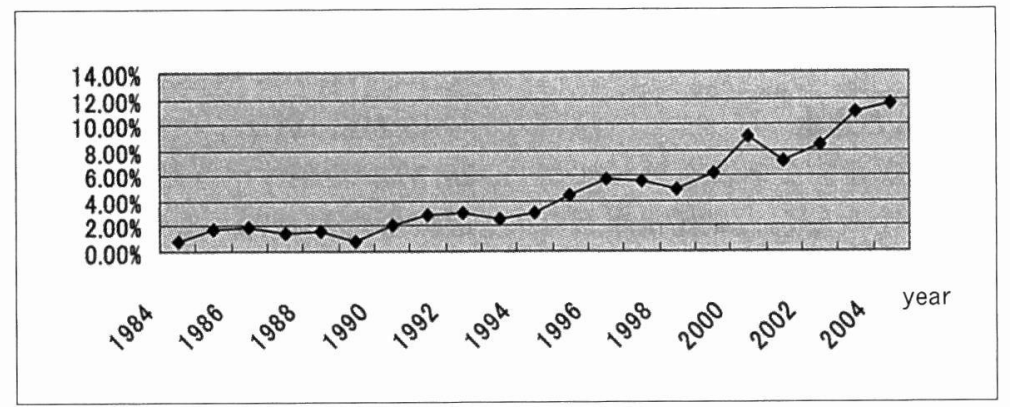

Fig. 1 The rate of female certified surgeons by Japan Surgical Society

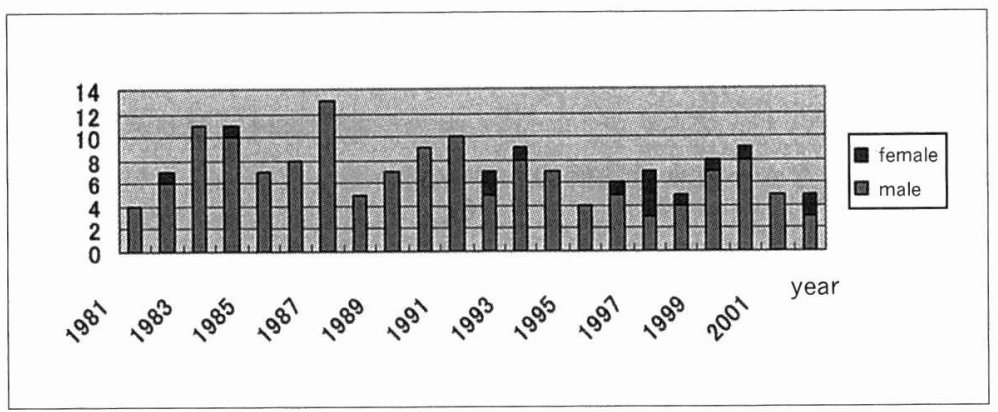

Fig. 2 The rate of new female surgeons in Second Department of Surgery, Yokohama City University, School of Medicine

\section{女性医師の労働環境}

北海道保険医会女性部会の女性研修医の勤務体 制に関するアンケート調查によれば，妊娠育児に ついて休暇や労働時間，業務内容の対応方法を具 体的に検討しているかの質問には $33 \%$ 病院は 規定を定め正職員に準じるとの回答だが，54\%の 病院は未検討, ケースにより判断とのことである。 また産前, 産後の休㗇があっても研修復帰後の扱 いが決まっていない，保育施設が 5 割以上の病院 でないとのことである゙)。日本小児科学会の全国 小児科医師現状調査における女性医師の回答から も，仕事を続けるうえでの支障は $43.3 \%$ が育児， 34.5\%が妊娠出産をあげているとのことで，出 産育児に関する支援は女性医師が活躍するために 最も改善しなければならない問題であると思われ る。

\section{3. 女性外科医師の人数と実態}

人数が少ないといわれる外科について具体例を 調べてみた。外科では外科学会認定医制度が 1984 年から制定されたので, 申請者の男女比から女性 医師の占める割合の推移を検討してみた（外科学
会事務局のご好意による)。1990 年までは毎年 $2 \%$ 未満で推移したものが以後急速に増加し続け ており, 2004 年は $11.6 \%$ にまでなったが全体の人 数合計はまだ $5 \%$ であった (Fig. 1)。次に横浜市 立大学第二外科学教室の女性入局者について医局 が開設された 1949 年から現在まで検討した $($ Fig. $2) 。 1983$ 年に初めて女性入局者があり, 1986 年 に二人目 (筆者) で以後しばらく入局がなかった が 1994 年以後急激に増加した。男性入局者が減少 する中, 1997 年は半数以上が女性であった。現在 勤務している医局員 127 人中 13 人, $10.2 \%$ が女性 である。うち結婚している女性は 5 人 $(38 \%)$, 子 供のいる女性は 3 人 (23\%) である。従来ほとん ど女性入局者がなかった外科になぜ増加している のであろうか。在籍女性医局員に外科を選択した 理由と躊躇した点，外科勤務を続けるうえでの問 題点を尋ねた。

\section{女性医師が外科入局を選択した理由}

仕事が面白く, やりがいがある $100 \%$, 外科(手 術）が好きである $77 \%$ ，手術で治すことができる $54 \%$ ，自分の性格にあっている $46 \%$ ，グループ診 


\section{日本外科系連合学会誌 第 31 巻 2 号}


(重複回答あり)。

\section{女性医師が入局を躊躇した理由}

先輩医師から女性は歓迎しない旨を言われた $15 \%$ (いずれも 1980 年代の入局), 結婚出産との 両立に不安がある $38 \%$, 非常に忙しく勤務時間が 長い, 土日も休めない $23 \%$ ，体力が続くか不安 $8 \%$ であった。現在入局してくる若い女性医師た ちは不安で尻込みするというよりは外科の魅力の 方が大きく，問題があっても自力で解決して，家 庭や育児との両立もうまくこなしてゆこうとする 姿勢がみられた。質問をしていて大きな意欲が感 じられ，躊躇することは少ないようであった。

\section{外科入局を考えたが, 入局しなかった女性医師の 意見}

外科入局も考えたが他科に進んだ著者の先輩, 同僚，後輩の女性医師に意見を尋ねた。入局に医 局員から難色を示された。家事と両立しない, 出 産育児と両立できない，帰宅が遅い，疲れる，研 修で先輩医師が女性医師には指導してくれなかっ たなどであった。

\section{受診者が女性医師に求めるもの}

医療の内容は医師の性別とは無関係なことが多 いが，性別による特異性のある訴之もある。受診 者は半数が女性であるが，医師は男性の比率が高 く, 不均等である。女性は特有の差恥心から乳腺, 肛門などの診察に同性の医師を希望する場合が多 く，更年期や月経前緊張症のように疾患とはいえ ないが苦しい場合，職場や家庭の人間関係，介護 の問題も絡んでつらい場合などは男性医師に訴之 てもわかってもらえない，同性の医師に相談した いと希望する場合も多い。このような受診者の要 望に答えて，個人を大切にして全人的医療を行う 医療として開設されたのが女性外来である。平成 13 年頃から各地に設置され，平成 17 年には 300 を超える数となった。当院女性外来受診者にアン ケート調査を行い，女性外来に求めるものは何か を質問した。

質問内容は 1 .女性外来を受診した理由は何か, 2.同じ主訴ですでに受診しているかどうか， 3 . 担当医は女性に限るかどうか，4，女性に限定す る理由，5，女性外来に求めるものを質問した。
結果は 1。女性外来を選択した理由は担当医が 女性であるから $84.2 \%$ ，女性特有の疾患であるか ら $45.6 \%$, プライバシーの保護を期待したから $26.3 \%$ ，受診すべき科の選択に迷って総合外来を 選択した $15.8 \%$ ，紹介を受けたため $7 \%$ \%゙っ た。2．女性外来を受診した主訴ですでに他の外 来を受診したかどうかの質問には受診あり $49 \%$, 受診なし $51 \%$ であった。一般の外来では説明が不 十分であった可能性が考えられた。3，診察後担 当医は男性でも良いと思ったかどうかの回答は男 性でも良い $17.5 \%$ ，女性でなくてはならない 82. 5\%であった。4.女性医師でなくてはならない理 由の記載内容は, 男性医師はデリカシーがなく話 を聞いてくれない，女性特有の悩みを理解しても らえなかった，男性医師の診察には身構えてしま うが女性医師は安心してリラックスして相談でき る，同性でなければ伝わらない二ュアンスがある と思う，未成年の女子の場合には男性医師の診察 は抵抗がある，ジロジロ見られたり，触れられる のが嫌である，過去の診察で無神経で失礼な言動 があった，粗暴な診察で苦痛が強かったなどで あった。 5 ．女性外来に期待するものは何かとの 質問に対する回答はゆっくり話を聞いてもらえる $84.2 \%$ ，プライバシーが守られる $66.7 \%$, 性差を 考慮にいれた診療を期待する $22.8 \%$ であった。女 性外来に求められていることは個人のプライバ シーを大切にして同性の医師にゆっくり話を聞い て相談に乗ってほしい，状態の説明をしてほしい ということであるといえる。

\section{女性医師の意識調查}

18 総合病院で女性外来を担当している 36 名の 女性医師を対象に，1. 従来の自分の専門科の外 来と女性外来では差があるかどうか， 2 ，差はど のような違いか， 3 ．外来診療を行う上で自分の 意識に変化がおこったかどうかを質問した。結果 は 1.92\%の医師が女性外来は特殊で従来の外来 とは差があると回答した。差がないと答えた医師 は精神科, 耳鼻科, 神経内科が専門の医師であり， 総合外来としての女性外来を担当しているという よりは協力科の一人として専門分野を担当してい るためと思われた。2, 異なる点については, 専 門科目にかかわらず受診者の話を聞くことの重要 


\section{2. 女性外科医師の進出と今後}

性が $39 \%$ ，専門分野以外でもオールラウンドに診 察する必要性 36\%，新たな幅広い領域の勉強，特 に婦人科領域や精神科領域, 性差医療, 漢方治療, カウンセリング技術などの必要性 36\%であった。 3. 診療に向き合う姿勢で変化したこととして, 受診者と一緒になって治療方法を相談するように なった，女性としての人生の全体像を考えるよう になった，保健所や他機関との連携をとるように なったなどが挙げられた。また診療内容ではない が，身だしなみ，話し方に気を配る，話に自分の 生き方まで反映される気がするなどの意見も聞か れた。

\section{考察}

歴史的に日本社会では女性は家庭の中にいて家 を守るものという考之が支配的で，特に男性中心 の医学の領域では女性医師の進出を歓迎しなかっ たようである。しかし屈辱的な診察を嫌い，同性 医師の診察を熱望した女性受診者と女性医師の熱 意により女性医師の足跡はずっと途切れることな く続いてきた。戦時中は男性に代わって活躍もし てきた。現在医師になる 3 人に 1 人は女性という 時代となり，増加傾向にある。しかし科による偏 りも多く，内科，皮膚科，眼科，小児科には女性 医師が多いが，外科系には少ない。さらに人数だ けの問題ではなく，教職についている女性医師は 少なく，特に国公立大学の臨床系科目においては 非常に稀である。また学会の役員なども少なく， リーダーシップをとって活躍している女性医師は 人数の比率以上に少ないことがわかった。原因は 社会の男性優位という体制もあるのかもしれない が，医師となっても家庭と仕事の両立の負担は大 きく，全力で仕事だけに没頭できない背景もある のかもしれない。

特に外科系には女性医師が少ないが, 近年増加 傾向にあることがわかった。皮膚科，眼科，内科 と比較して人数が少ない原因は，女性医師の意見 調查から，外科系領域は勤務時間が長く，急患や 容態の急変も多く，夜間，出勤も多い，医学部卒 業後研修，技術を習得する時期が結婚出産子育て と重なってしまう，医師には保育所など子育て支 援もなく，当直業務の免除もないため，両立でき
ずに途中であきらめてしまう，などであった。過 去長いこと外科の医局は男性社会であり，女性を 排除する風潮があり，女子用の更衣室や当直室も なく，また育成しようとしても先に述べたような 理由で女子は途中で辞めてしまう場合が多いた め, 先輩の医師も本気で女性外科医を育てようと しなかったこともあった。しかし，受診者の同性 医師の診察を希望する声が高まり，また先陣を 切った女性医師の活躍により各医局, 病院でも女 性を否定する意見が少なくなり，外科系に進出す る女性医師は増加してきた。以前は家庭や子供を もつことをあきらめてやっと男性と対等に外科勤 務ができる状態であったが，近年入局してくる女 性外科医師は皆，結婚も出産もしたいと希望して いる。外科に限らず女性医師は男性と対等に勤務 したいと希望している。家事, 妊娠, 出産, 育児 を抱えると男性と全く同等に勤務できるとは限ら ない。特に出産前後や授乳中の一時期は時間，体 力でも非常に制約を受ける時期もあると考之られ る。しかし女性にしかできない細かい配慮や気配 り，特質を生かした医療は，受診者のニーズに応 え，男性だけの医療では不足する面を補うことが できる。少人数でも女性が男性医師の中に混じる ことで医療の質を向上することができると思われ る。また，短期的には労働力として男性より劣る かもしれないが, 子育てが一段落した後復帰して 通常通り勤務することができれば，長期的には十 分に労働力に值すると考えられる。長期的に家庭 と両立して勤務できる環境の整備が大切である。 また，結婚，妊娠，育児を経験することで人間味 豊かで女性らしい配慮のある質の高い医療も可能 になると思われる。特に女性外来の需要から見る と女性特有の苦痛に共感を持って, 受診者の話を 聞くこと，ホルモンの影響を加味して健康な女性 の社会生活を支えるための相談にのること，恥ず かしいと思う気持ちを尊重して不快感の少ない, 丁寧で親切な診察をすることが求められている。 医師としては狭い自分の専門領域だけでなくプラ イマリーケアーに習熟し，精神面も含めた多面的 な対応ができるように勉強する必要がある。人生 経験を積んだ女性医師は人間的にも今後ますます 求められてくると思われる。医療には骨折の治療 
や消化器癌手術のように男女を問わないものも多 い。しかしそれだけでは受診者から求められてい るものに答えられず，不足していたものがあった ので，女性外来が一気に全国に波及したのだと思 われる。女性医師は女性であるというだけではだ めで，この求められているものへの自覚を持ち， 苦痛に共感し，受診者の健康な社会生活を支える という姿勢を持つことが必要である。また家庭や 体調の都合で十分働けないこともあるが，甘える ことなく職場の男性医師やスタッフと上手に協力 して勤務する努力も必要である。この 3 年間で女 性医療を行う上で必要な情報を互いに学び合いた いという要望から「女性医療ネットワーク」,「性 差医療研究会」が発足し，また女性医師の活躍を 互いに助け合おうと「女性医師のキャリア形成・ 維持・向上をめざす会」も発足した。これからま すます自覚をもった女性医師の進歩活躍が期待で きる。勤務先である病院や地域でも，保育所や子 育て支援サービス，介護サービスを充実して女性 医師が働きやすい環境が整備されることを希望す る。

\section{まとめ}

女性医師には男性と対等な部分と異質な部分が ある。性格も考之方も，妊娠出産するという体の 構造も異なっている。女性受診者が求める点に関 しては積極的に協力し, 男性受診者に対しても細 やかな配慮や気配りで気持ちを和やかにできた ク，優しい話し方で不安を取り除いたりすること が可能である。男性医師には女性にはない強い腕 力や長時間働ける体力もあり, 女性医師はかなわ ない点も多い。お互いの長所を十分に発揮し，短 所を補いながら協力して仕事を続けていくこと が, 受診者にとって最も望まれる医療ではないだ ろうか。地域, 勤務先は子育て, 介護支援で女性 医師の労働力を確保し, その能力をフルに引き出 し, 活用することで, 受診者の満足が得られるよ う努力されんことを期待したい。

\section{参考文献}

1）橋本葉子：女性医師と医療. 病院 61：700-703, 2002

2）中谷祐貴子, 中島正治：日本の女性医師の現状と 動向. 病院 $61: 712-715,2002$

3）荒木葉子：女性医師の学会活動の現状. 医学教育 $33: 51-57,2002$

4）島津英昌：女性医師の労働環境は，いま.JAMIC JOURNAL : 14-23, 2004 